Review

\title{
A critical review of electrode materials and electrolytes for Low- Temperature Lithium-Ion Batteries
}

\author{
Tatiana L. Kulova, and Alexander M. Skundin*
}

Frumkin Institute of Physical Chemistry and Electrochemistry of the RAS, 119071 Moscow, Russia *E-mail: askundin@mail.ru

doi: $10.20964 / 2020.09 .50$

Received: 8 June 2020 / Accepted: 4 July 2020 / Published: 10 August 2020

The critical analysis of literature of last 15 years, concerning features of low-temperature behavior of lithium-ion batteries is presented. Certain approaches to the problem; the role of different constituents of electrode polarization at low temperatures; features of functioning of negative and positive electrodes are reviewed. Low-temperature electrolytes are reviewed as well.

Keywords: lithium-ion batteries, low temperatures, electrode polarization, low-temperature electrolytes.

\section{$\underline{\text { FULL TEXT }}$}

(C) 2020 The Authors. Published by ESG (www.electrochemsci.org). This article is an open access article distributed under the terms and conditions of the Creative Commons Attribution license (http://creativecommons.org/licenses/by/4.0/). 